
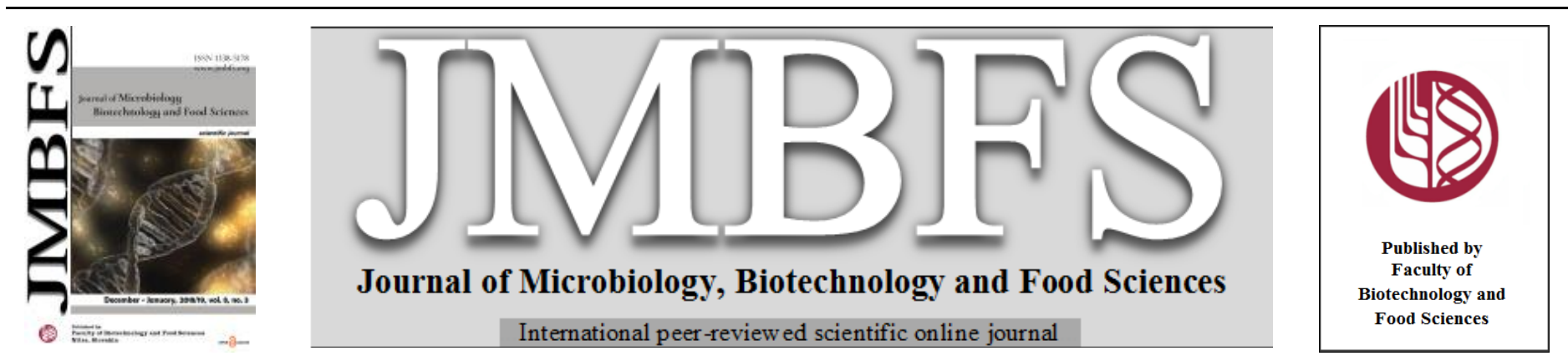

\title{
ASSESSMENT OF HEMATOLOGICAL AND BIOCHEMICAL EFFECTS OF ACUTE AND CHRONIC ADMINISTRATION OF THE STENOTROPHOMONAS MALTOPHILIA LYSATES IN MICE
}

\author{
Chattopadhyay Moitreyee, Das Debalina, Das Dibyajyoti, Gupta Malaya, Bagchi Gautam Kumar*
}

Address(es): Dr. B.C.Roy,

College of Pharmacy and Allied Health Sciences, Dr Meghnad Saha Sarani, Bidhan nagar, Durgapur, West Bengal. India.

*Corresponding author: pharmacol2015@gmail.com

doi: $10.15414 / j m b f s .2018-19.8 .3 .936-939$

\section{ARTICLE INFO}

Received 9. 4. 2018

Revised 7. 10. 2018

Accepted 9. 10. 2018

Published 1. 12. 2018

Regular article open $\partial_{\text {ACCESS }}$

\begin{abstract}
The contamination of rice with microorganisms during the storage is very common. In the present study we observe the effect of consumption of such contaminated rice and the lysate obtained from the microorganism on the hematological and biochemical parameters. Among all the microorganisms the bacteria exhibiting gross alteration on the locomotor effect was identified by the $16 \mathrm{~s}$ rRNA sequencing of the bacteria which is found to be Stenotrophomonas maltophilia. The lysate obtained from the bacterial strain gave an $\mathrm{LD}_{50}$ value more than $2000 \mathrm{mg} / \mathrm{kg}$ p.o. Though acute exposure to the lysate reduced the locomotor activity but no such effect was observed for the chronic exposure. The study exhibited that at $200 \mathrm{mg} / \mathrm{kg}$ p.o. and $300 \mathrm{mg} / \mathrm{kg}$ p.o. for a period of 15 days administration the hematological and biochemical profile was unchanged. Though at chronic exposure of $200 \mathrm{mg} / \mathrm{kg}$ p.o. there was no change in the hematological and biochemical parameters but a long term exposure of the lysate at $300 \mathrm{mg} / \mathrm{kg}$ p.o. reduced hemoglobin and red blood corpuscles count. Moreover, at the higher dose exposure there was an increase in the liver enzymes Alanine aminotransferase (ALT), aspartate aminotranferase (AST) and alkaline phosphatase (ALP). Thus, it indicated that at higher dose long term exposure the lysate of Stenotrophomonas maltophilia may be responsible for toxic changes in the body.
\end{abstract}

Keywords: Stenotrophomonas maltophilia, 16s rRNA, Hematology, Biochemistry

\section{INTRODUCTION}

In the recent times the word contamination has started an alarming situation in the world. The contamination is very common and the food contaminants reduce the quality of the food which when ingested are responsible for multiple diseases which may be life threatening at times. The contamination starts from the cultivation process till the ingestion of the food. The contaminants though are of physical, chemical and microbiological but most of the food associated infections are the result of the multiplication of various microorganisms and the toxins produced by them. The food is the carrier for pathogens which are the causes of numerous diseases (Vemula et al., 2012).

The tropical country faces the problem of contamination more due to the warm and humid climate which gives the optimum environment for the microbial growth. The contamination can be present both in the cooked as well as uncooked food (Haque and Russell, 2005). During storage of the raw food material the microbial contamination increases due to the improper storing methods. Usually the growth of microorganism is common in the cooked food after storage. The cooked food is supposed to kill the bacteria but the toxins generated by them usually remains in the food. The ingestion of the contaminated food develops the gut diseases and also affects the other part of the body. The tendency for the growth of microorganism varies with the crops. Rice forms the staple diet for large number of population mainly in the Asian countries. Rice one of the most commonly used cereals which has the weakness for the growth of multiple microorganisms like Enterobacteriaceae, Bacillus spp., and Pseudomonas spp. Aspergillus spp. and Penicillium spp. (Cottyn et al., 2001; Oh et al., 2007) and production of many toxins occur in rice which act as the common growth environment. Approximately, India consumes 97,000 metric tons of rice yearly and exports approximately 12,500 metric tons and the country is one of the major producers of rice in the world (https://www.statista.com). Data also represents that around $50-60 \%$ loss of cereals occur due to poor storage, contamination and inefficient technology (Kumar and Kalita, 2017). There are studies in relation to the common contaminants and the adverse health effects observed due to ingestion of the contaminants. In the initial study certain microorganisms were isolated from the contaminated rice and later their effects were studied on the various behavioral activities of the mice. In the previous study it was observed that one of the microorganisms brought about elaborate changes in the behavioral parameter which reflected depression. The altered behavioral changes therefore helped in the further investigations and the present study was framed with the objective: i) to identify the microorganism obtained from the contaminated uncooked rice, ii) to determine the $\mathrm{LD}_{50}$ value of the extract obtained from the microorganism and iii) to investigate the effects of the extract obtained from the microorganism on the hematological and biochemical parameters in mice.

\section{MATERIALS AND METHODS}

Rice bacteria collection

Fifty rice samples were obtained from storehouses where the rice was kept in sacks in large heaps. $1 \mathrm{~g}$ of each rice sample was suspended in $10 \mathrm{ml}$ of sterile normal saline. Four dilutions $10^{-1}, 10^{-2}, 10^{-4}$ and $10^{-6}$ were made with sterile normal saline. $0.1 \mathrm{ml}$ of each dilution was aseptically inoculated on modified Soyabean casein digest agar medium in duplicates containing $1 \%$ rice powder (Soyabean casein digest Medium, Tryptone soy broth, HiMedia Laboratories Pvt Ltd, Mumbai, India; Nice Chemicals P. Ltd., Kochi, Kerela, India). Incubation was done at an ambient temperature of $29^{\circ} \mathrm{C}$ for $24 \mathrm{~h}$. Four different colonies of bacteria were isolated by the streak plate (Sanders, 2012) which was further grown in the modified soyabean casein digest agar medium.

\section{Bacterial cell debris and lysate Preparation}

The bacterial strains obtained were grown on rice powder modified soyabean casein digest medium which was washed and suspended in $50 \mathrm{ml}$ of sterile normal saline. The suspended cellular material was heated at $80^{\circ} \mathrm{C}$ for 10 mins (Ren $e t$ al., 2007). The cellular suspension along with the lysate was lyophilized.

In the initial phase of the study, a neurobehavioral screening (Irwin test) was done with each of the four bacterial lyophilized cellular materials at a concentration of $1 \mathrm{mg} / \mathrm{ml}$. The dead bacterial cells and lysate of a strain showing reduced locomotor activity in mice was selected for further studies. 


\section{Bacterial identification by $16 \mathrm{~S}$ rRNA sequencing}

The bacterial identification by $16 \mathrm{~S}$ rRNA sequencing has been performed in MTCC (Microbial Type Culture Collection and Gene Bank, Chandigarh, India) as per standard protocol. Briefly, $16 \mathrm{~S}$ rRNA gene being the housekeeping genetic marker was used for the identification and sequencing of the bacterial phylogeny and taxonomy. The genomic DNA was extracted from the pure culture of the test organism. Using the genomic DNA as template, PCR amplification of 16s rRNA (1400 bp in length) was performed with suitable primers and the products obtained were purified (Clarridge, 2004). The PCR product of the ribosoma RNA was sequenced and subsequently was undertaken as query sequence to investigate homologous sequences through nucleotide BLAST (NCBI) (Altschulz et al., 1990). The "best hit" organism having maximum identity match with the query sequence, has been taken as source organism for the 16s rRNA.

\section{ANIMAL STUDIES}

\section{Experimental animals}

Fifty five adult Swiss Webster mice of either sex weighing between 18 and $22 \mathrm{~g}$ were obtained from the CPCSEA approved animal house of Dr. B. C. Roy College of Pharmacy and Allied Health Sciences, Durgapur. The animals were housed five per cage under the 12-hr light/dark cycle (lights on at 06:00 hrs, lights off at 18:00 hrs) at a constant temperature of $24 \pm 1{ }^{\circ} \mathrm{C}$. For acclimatization mice were housed a week prior to the study in the laboratory conditions. Food and water were available ad libitum throughout the study period. This study was performed according to the guidance of Committee for the Purpose of Contro and Supervision of Experiments on Animals (CPCSEA) guidelines and Institutional Animal Ethics Committee (IAEC).

\section{Preparation of dose for $\mathrm{LD50}$ determination}

For LD50 determination the dose was considered as $2000 \mathrm{mg} / \mathrm{kg}$ p.o. in mice with a dosing volume at $10 \mathrm{ml} / \mathrm{kg}$ for the mice. The lyophilized cell debris and extract was dissolved in sterile normal saline at a concentration of $200 \mathrm{mg} / \mathrm{ml}$

\section{Method for LD50 determination}

The LD50 study was done according to the OECD (Organization for Economic Co-operation and Development) guideline 425 for the acute oral toxicity by the up and down procedure (OECD/OCDE 425). The limit test for $2000 \mathrm{mg} / \mathrm{kg}$ p.o. was performed. The test substance was administered in a single dose by gavage needle. Five female mice were selected randomly for the study. One animal was administered with the test dose and observed for its survival. As the previous animal survived later four additional animals were dosed. In the entire test period all five animals survived in the administered dose.

Animals were observed individually after 30 minutes of dosing and periodically during the first $4 \mathrm{hrs}$ continuing it for 24 hours. Observations were done for a period of fourteen days to find the changes in skin and fur, eyes and mucous membranes, respiratory, circulatory, autonomicand central nervous systems and behavioral pattern. The locomotor activity of the mice were detected in the actophotometer (Make: MVTEX, Ambala, Haryana, India) for a period of 5 mins. The equipment is a square shaped closed area $(30 \times 30 \times 30 \mathrm{~cm})$ having six photocells on the walls. The interruptions of the photocells attached to a digital counter recorded the locomotor activity. The reading was recorded by placing individual animal before treatment, 30mins and $4 \mathrm{hrs}$ post treatment (Bhosale et al., 2011)

Table 1 Ez Taxon Result of the contaminated bacteria from rice sample.

\begin{tabular}{|c|c|c|c|c|c|}
\hline SNo & Name & Strain & $\begin{array}{l}\text { Pairwise } \\
\text { similarities } \\
(\%)\end{array}$ & $\begin{array}{l}\text { Differential/total } \\
\text { nucleotides }\end{array}$ & Completeness (\%) \\
\hline 1. & Stenotrophomonas maltophilia & MTCC 434(T) & 99.86 & $2 / 1399$ & 100 \\
\hline 2. & Stenotrophomonas pavanii & ICB 89(T) & 99.57 & $6 / 1399$ & 100 \\
\hline 3 & Pseudomonas hibiscicola & ATCC 19867(T) & 99.43 & $8 / 1396$ & 98.8 \\
\hline 4. & Pseudomonas beteli & ATCC 19861(T) & 99.36 & $9 / 1397$ & 97.1 \\
\hline 5. & Pseudomonas geniculata & ATCC 19374(T) & 99.35 & $9 / 1394$ & 97.1 \\
\hline 6. & Stenotrophomonas chelatiphaga & LPM-5(T) & 98.50 & $21 / 1399$ & 98.8 \\
\hline 7. & Stenotrophomonas rhizophila & DSM 14405(T) & 97.64 & $33 / 1399$ & 100 \\
\hline 8 & Stenotrophomonas humi & $\mathrm{R}-32729(\mathrm{~T})$ & 97.28 & $38 / 1399$ & 100 \\
\hline 9 & Stenotrophomonas panacihumi & MK06(T) & 97.21 & $39 / 1399$ & 99.2 \\
\hline 10 & Stenotrophomonas nitritireducens & $\mathrm{L} 2(\mathrm{~T})$ & 97.13 & $40 / 1396$ & 100 \\
\hline
\end{tabular}

The BLAST analysis of the test16S rRNA gene sequence revealed an identity of $99.86 \%$ with that of Stenotrophomonas maltophilia as mentioned in the Table1. Only 2 nucleotides of the test 16s rRNA (1400 bp) showed difference with the corresponding rRNA sequence of Stenotrophomonas maltophilia (Table 1).

Thus, from the results, it is observed that Stenotrophomonas maltophilia has the best identity match the test sequence due to both its minimum differential count
Assessment for Biochemical and Hematological changes

The mice were given the solution of the bacterial cellular debris orally. Two different doses were selected for the study $(200 \mathrm{mg} / \mathrm{kg} ; 300 \mathrm{mg} / \mathrm{kg})$. Same doses were administered on different groups of animals for different times (15 days and 3 months). The control group was separate and did not receive any treatment. All the comparisons were performed after treatment together with the control. Accordingly mice were grouped into five each having ten mice, which are as follows: Group I- Untreated control, Group II- Received dose at $200 \mathrm{mg} / \mathrm{kg}$ p.o. for 15 days daily, Group III- Received dose at $300 \mathrm{mg} / \mathrm{kg}$ p.o for 15 days daily, Group IV- Received dose at $200 \mathrm{mg} / \mathrm{kg}$ p.o. once a week for 3 months and Group $\mathrm{V}$ - Received dose at $300 \mathrm{mg} / \mathrm{kg}$ p.o. once a week for 3 months. After the entire study all animals were euthanized with carbon monoxide. Five animals from each group were separated and blood was collected in $10 \% \mathrm{w} / \mathrm{v}$ potassium EDTA containing tube (Fisher scientific, Mumbai) for hematological analysis. The blood from rest of the five animals from each group was collected and was centrifuged at $1,500 \mathrm{x}$ g for $10 \mathrm{~min}$ at $4^{\circ} \mathrm{C}$ to separate the serum from blood for the biochemical analysis. The serum was used to determine liver function by measuring the serum bilirubin, direct bilirubin, indirect bilirubin, aspartate aminotransferase (AST), alanine aminotransferase (ALT), alkaline phosphatase, total protein, serum albumin and serum globulin levels. The renal function was determined by the measurement of urea, uric acid and creatinine level in serum. The tests of liver function and renal function were performed using the commercial disposable kits from Swemed Biomedicals Private Ltd. (Yelachenahalli, Bengaluru, India).The blood was collected by cardiac puncture. The hematological analysis was carried out with Siemens ADVIA-60 hematology Analyzer and the biochemical analysis was done in Touch Screen Biochemistry Analyzer, Labtronics, India (Parasuraman et al., 2010).

\section{Statistical analysis}

The data obtained was analysed statistically using ANOVA followed by Student T-Test. The comparison was done between the control group of animals with each treated group of animals. The $p$ values $<0.05$ were considered significant.

\section{RESULTS AND DISCUSSION}

In the present study the microorganism was selected that was found in the uncooked rice with the intention that many times improper washing of the raw food materials lead to health problems and sometimes many organisms have been found that being thermolabile they are not killed or the lysate and the cellular debris present in the cooked sample lead to various diseases over repeated consumption and contaminated food consumption leads to outbreak of diseases (Yamaguchi et al., 2018)

\section{Identification of bacterial strain obtained from contaminated rice}

Stenotrophomonas maltophilia is an aerobic Gram negative bacilli found to have well growth as tiny colonies (Figure 1) in the soyabean casein digest agar medium containing $1 \%$ rice powder, 24 hours after incubation.

The BLAST analysis of the 16s rRNA sequence was completed for the bacteria obtained from contaminated rice. The sequencing was done for the length of 1400-bp which depicted the result as given in Table 1.

with the test sequence as well as maximum pairwise similarity with the same Hence the test organism has been identified as Stenotrophomonas maltophilia. 


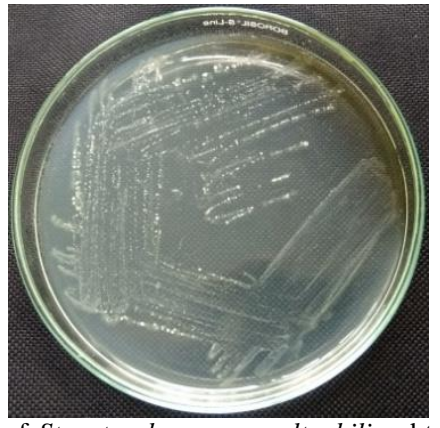

Figure1 The colony of Stenotrophomonas maltophilia obtained by streak plate method

\section{LD50 value of Stenotrophomonas maltophilia dead cell and lysate}

The study was conducted following the OECD guideline 425 . The limit test for $2000 \mathrm{mg} / \mathrm{kg}$ for acute oral toxicity study was selected. The LD50 of the Stenotrophomonas maltophilia cell lysate was found to be more than $2000 \mathrm{mg} / \mathrm{kg}$ as no death occurred neither in the first $24 \mathrm{hrs}$ of dosing nor in the entire period of 14 days of observation (OECD/OCDE 425). The limit test of $2000 \mathrm{mg} / \mathrm{kg}$ was considered as the sudden or acute consumption of the contaminated rice usually did not show any health related problems but chronic exposure may develop harmful effects. The animals were observed for 14 days but no alterations were found in the fur quality and quantity, eyes activity, mucous membranes, respiratory, circulatory and autonomic nervous systems. A reduction in the locomotor activity was observed after 30 mins and 4 hours post treatment as given in Table 2 .

Table 2 Effect of Stenotrophomonas maltophilia cell debris and lysate on the Locomotor Activity using Actophotometer

\begin{tabular}{lll}
\hline Group & Locomotor activity & \% Reduction in activity \\
\hline Before treatment & $368.6 \pm 15.04$ & 69.72 \\
\hline 30mins post treatment & $111.6 \pm 5.98 * *$ & 41.5 \\
\hline 4 hrs post treatment & $215.62 \pm 9.02 * *$ & 5.96 \\
\hline 24 hrs post treatment & $346.6 \pm 11.99$ & all values are Mean $\pm S D, n=5, * P<0.05, * * P<0.001$ when compared with animals before treatment
\end{tabular}

There was a very high significant reduction in locomotor activity observed both in the 30 mins and $4 \mathrm{hrs}$ post treatment with the Stenotrophomonas maltophilia lysed cell which was found to be $111.6 \pm 5.98$ and215.62 \pm 9.02 , respectively, when compared with the locomotor activity of the animals before the treatment with the cell extract that was $368.6 \pm 15.04$. But after 24 hours the same treated animals did not show much change in the locomotor activity which was $346.6 \pm$ 11.99 with a reduction of only $5.96 \%$. The assessment of locomotor activity is considered as the index for alertness. The reduction in the locomotor activity is usually caused by the inhibitory action of the CNS which may be the result of reduction in the central nervous system functions such as sedation and anxiolysis (Mahendran et al., 2014). The anxiogenic condition is reported to cause increased locomotion (Carpenter $\boldsymbol{e t}$ al., 2007). The reduced locomotor activity could be due to interference of the Stenotrophomonas maltophilia cell lysate with the GABA ergic receptors mainly $\mathrm{GABA}_{\mathrm{A}}$ (Asinof and Paine, 2013). The serotonin plays a major role in anxiety and locomotion and may be Stenotrophomonas maltophilia cell lysate plays a role in reducing the serotonergic pathway (Pum et al., 2009). The reduced muscle tone is also a cause of the reduced locomotor activity because the motor loop of brain step and spinal cord is responsible in proper gait (Takakusaki et al., 2016).

Biochemical and Hematological effects of Stenotrophomonas maltophilia dead cell and lysate

The effect of the lysate of Stenotrophomonas maltophilia on biochemical and hematology of mice is elaborated in the Table 3 and Table 4. A reduction in the hemoglobin concentration and RBC count was noted in Table 3 . The reduction in hemoglobin concentration was only at the chronic treatment of the lysate at a high dose of $300 \mathrm{mg} / \mathrm{kg}$ p.o. which was statistically significant $(\mathrm{p}<0.05)$. This indicates that the lysate could disrupt hemoglobin production at a higher dose. The hemoglobin reduction occur due to multiple factors like iron deficiency anemia, thalassemia or due to chronic infections. Iron which is stored in RBC is an essential component of hemoglobin. Loss of iron led to decrease in hemoglobin formation (Johnson-Wimbley and Graham, 2011). The reduction in RBC may be due to oxidative damage to the cell membrane. A decreased RBC indicates that the Stenotrophomonas maltophilia cell lysate suppressed the hemopoietic system. The decreased RBC and hemoglobin in the hematological index in chronic exposed mice indicates destruction of erythrocyte (Dede $\boldsymbol{e t}$ al. 2002). In the biochemical parameters after chronic treatment with the Stenotrophomonas maltophilia lysate at $300 \mathrm{mg} / \mathrm{kg}$ it was observed that the levels of Alanine aminotransferase (ALT), aspartate aminotranferase (AST) and alkaline phosphatase (ALP) increased with marked significance $(\mathrm{P}<0.001)$ as reflected in Table 4. Liver is the major organ for metabolism and its enzymes are essential for normal metabolism (Rajamanickam and Muthuswamy, 2008)

The enzymes Alanine aminotransferase (ALT), aspartate aminotranferase (AST) and alkaline phosphatase (ALP) are the indicators of hepatocellular function (Thapa and Anuj, 2007). These enzymes are normally present in the cytoplasm which is released into the circulation as the consequence of cellular damage (Giannini et al., 2005). The lysate obtained may have caused hepatocellular injury damaging the structural integrity leading to high enzyme levels.

Table 3 The Effect of lysate obtained from Stenotrophomonas maltophilia on hematological parameters in mice

\begin{tabular}{|c|c|c|c|c|c|}
\hline & Untreated & $\begin{array}{l}\text { Dose }: \mathbf{2 0 0 m g} / \mathrm{kg} \\
15 \text { days }\end{array}$ & $\begin{array}{l}\text { Dose }: \mathbf{3 0 0 m g} / \mathrm{kg} \\
15 \text { days }\end{array}$ & $\begin{array}{l}\text { Dose : 200mg/kg } \\
3 \text { months }\end{array}$ & $\begin{array}{l}\text { Dose : 300mg/kg } \\
3 \text { months }\end{array}$ \\
\hline Hemoglobin (G/dl) & $13.1 \pm 0.22$ & $12.6 \pm 0.55$ & $12.32 \pm 0.42$ & $12.68 \pm 0.20$ & $9.48 \pm 0.85^{*}$ \\
\hline $\begin{array}{l}\text { Total leucocyte count } \\
\left(10^{\wedge} 3 / \text { cumm }\right)\end{array}$ & $8.07 \pm 0.127$ & $8.16 \pm 0.09$ & $7.96 \pm 0.19$ & $8.12 \pm 0.07$ & $7.85 \pm 0.08$ \\
\hline $\begin{array}{l}\text { Total RBC count } \\
\text { (mil/cumm) }\end{array}$ & $3.84 \pm 0.50$ & $4.16 \pm 0.43$ & $3.8 \pm 0.90$ & $3.58 \pm 0.61$ & $1.9 \pm 0.47 * *$ \\
\hline $\begin{array}{ll}\text { Platelet } & \text { count } \\
\left(10^{\wedge} 5 / \text { cumm }\right) & \end{array}$ & $3.09 \pm 0.05$ & $3.16 \pm 0.11$ & $2.94 \pm 0.11$ & $4.04 \pm 0.12$ & $3.74 \pm 0.41$ \\
\hline \multicolumn{6}{|l|}{ Differential count } \\
\hline Neutrophil (\%) & $56.4 \pm 3.21$ & $54.2 \pm 5.16$ & $58 \pm 5.43$ & $55.9 \pm 3.89$ & $55.6 \pm 3.21$ \\
\hline Lymphocyte (\%) & $34.8 \pm 2.95$ & $37.0 \pm 2.12$ & $34.0 \pm 3.67$ & $36 \pm 2.55$ & $34.8 \pm 3.03$ \\
\hline Eosinophil (\%) & $5.6 \pm 0.14$ & $5.3 \pm 0.29$ & $5 \pm 1.15$ & $4.8 \pm 0.54$ & $6 \pm 0.51$ \\
\hline Monocytes (\%) & $3.2 \pm 0.12$ & $3.5 \pm 0.12$ & $3 \pm 0.43$ & $3.3 \pm 0.38$ & $3.6 \pm 4.02$ \\
\hline Basophils (\%) & 0 & 0 & 0 & 0 & 0 \\
\hline
\end{tabular}

Table 4 The Effect of lysate obtained from Stenotrophomonas maltophilia on blood biochemical parameters in mice

\begin{tabular}{llllll}
\hline & Untreated & $\begin{array}{l}\text { Dose : 200mg/kg } \\
\text { 15 days }\end{array}$ & $\begin{array}{l}\text { Dose : 300mg/kg } \\
15 \text { days }\end{array}$ & $\begin{array}{l}\text { Dose : 200mg/kg } \\
3 \text { months }\end{array}$ & $\begin{array}{l}\text { Dose : 300mg/kg } \\
3 \text { months }\end{array}$ \\
\hline $\begin{array}{l}\text { Serum } \\
\text { bilirubin(mg/dl) }\end{array}$ & $0.56 \pm 0.05$ & $0.52 \pm 0.05$ & $0.5 \pm 0.08$ & $0.47 \pm 0.11$ & $0.53 \pm 0.13$ \\
\hline $\begin{array}{l}\text { Direct bilirubin } \\
\text { (Conjugated mg/dl) }\end{array}$ & $0.2 \pm 0.05$ & $0.22 \pm 0.05$ & $0.2 \pm 0.06$ & $0.21 \pm 0.12$ & $0.21 \pm 0.1$ \\
\hline $\begin{array}{l}\text { Indirect bilirubin } \\
\text { (Unconjugated mg/dl) }\end{array}$ & $0.36 \pm 0.03$ & $0.3 \pm 0.06$ & $0.3 \pm 0.07$ & $0.26 \pm 0.06$ & $0.32 \pm 0.5$ \\
\hline
\end{tabular}




\begin{tabular}{llllll}
\hline AST (U/L) & $30 \pm 2.54$ & $30.4 \pm 5.85$ & $29.8 \pm 5.76$ & $32.4 \pm 2.70$ & $101 \pm 7.81^{* *}$ \\
\hline ALT (U/L) & $31.8 \pm 3.83$ & $29.4 \pm 5.94$ & $27.8 \pm 4.60$ & $30 \pm 4.84$ & $69.6 \pm 4.15^{* *}$ \\
\hline $\begin{array}{l}\text { Serum Alkaline. } \\
\text { Phosphatase (U/L) }\end{array}$ & $6.6 \pm 1.14$ & $7.2 \pm 3.59$ & $8.6 \pm 2.61$ & $9 \pm 3.16$ & $75.2 \pm 6.14^{* *}$ \\
\hline $\begin{array}{l}\text { Total protein } \\
(\mathrm{g} / \mathrm{dl})\end{array}$ & $6.85 \pm 0.67$ & $7.2 \pm 0.38$ & $6.5 \pm 0.56$ & $7.4 \pm 0.49$ & $6.6 \pm 0.48$ \\
\hline $\begin{array}{l}\text { Serum Albumin } \\
\text { (g/dl) }\end{array}$ & $3.9 \pm 0.58$ & $4.1 \pm 0.56$ & $4.0 \pm 0.41$ & $4.3 \pm 0.52$ & $3.6 \pm 0.23$ \\
\hline $\begin{array}{l}\text { Serum Globulin } \\
(\mathrm{g} / \mathrm{dl})\end{array}$ & $2.95 \pm 0.36$ & $3.1 \pm 0.34$ & $2.5 \pm 0.34$ & $3.1 \pm 0.43$ & $2.96 \pm 0.35$ \\
\hline $\begin{array}{l}\text { Blood Urea (mg/dl) } \\
\text { Creatinine }\end{array}$ & $0.91 \pm 0.16$ & $30.8 \pm 7.4$ & $29.2 \pm 5.54$ & $32.6 \pm 7.63$ & $34.2 \pm 5.71$ \\
\hline $\begin{array}{l}\text { Serum } \\
(\mathrm{mg} / \mathrm{dl})\end{array}$ & $1.02 \pm 0.14$ & $1.1 \pm 0.17$ & $0.94 \pm 0.11$ & $1.05 \pm 0.11$ \\
\hline $\begin{array}{l}\text { Serum Uric acid } \\
(\mathrm{mg} / \mathrm{dl})\end{array}$ & $4.7 \pm 1.22$ & $5.56 \pm 0.92$ & $6.74 \pm 0.99$ & $6.08 \pm 1.01$ & $5.84 \pm 0.91$ \\
\hline
\end{tabular}

All values are Mean $\pm S D, n=5, * P<0.05, * * P<0.001$ when compared with untreated animals; AST:Aspartate aminotransferase, ALT: Alanine aminotransferase

\section{CONCLUSION}

The present study of the lysate of Stenotrophomonas maltophilia suggested that the ingestion of the bacteria Stenotrophomonas maltophilia even after cooking showed suppression in the locomotor activity. Moreover, the lysate on a long term may cause damage to the liver cells and also may be responsible factor for reduced RBC count which may lower the hemoglobin level.

Acknowledgement: We are thankful to the MTCC (Microbial Type Culture Collection and Gene Bank), Chandigarh, India for helping us in identifying the bacterial strain for further studies. We are also thankful to the CPCSEA approved animal house for providing us the facility for conducting the animal studies in the research.

\section{REFERENCES}

Vemula Rao, S., Kumar, N.R., Polasa, K. (2012). Foodborne diseases in Indiaa review. British Food Journal, 114, 661-680.

https://doi.org/10.1108/000707012112954

Haque, A., \& Russell, N.J. (2005). Phenotypic and genotypic characterisation of Bacillus cereus isolate from Bangladeshi rice. International Journal of FoodMicrobiology, 98 ,

34. https://doi.org/10.1016/j.ijfoodmicro.2004.04.025 $23-$

Cottyn, B., Regalado, E., Lanoot, B., De Cleene, M., Mew, T.W., Swings, J. (200 Bacterial populations associated with rice seed in the tropical environm Phytopathology, 91, 282-292. https://doi.org/10.1094/phyto.2001.91.3.282

Oh, J.Y., Jee, S.N., Nam, Y., Lee, H., Ryoo, M., Kim, K.D. (2007). 36 populations of fungi and bacteria associated with samples of stored rice in Korea. Mycobiology, 35, 36-38. https://doi.org/10.4489/myco.2007.35.1.036

Kumar, D., \& Kalita, P. (2017). Reducing postharvest losses during storage of grain crops to strengthen food security in developing countries. Foods, 6, 1-22. https://doi.org/10.3390/foods6010008

Sanders, E.R. (2012). Aseptic laboratory techniques: Plating methods. Journal of Visalized Experiments, 63, 1-18. https://doi.org/10.3791/3064

Ren, X., Yu, D., Yu, L., Gao, G., Han, S., Feng, Y. (2007). A new study of cell disruption to release recombinant thermostable enzyme from Escherichia coli by thermolysis. Journal of Biotechnology, 129, 668-673. https://doi.org/10.1016/j.jbiotec.2007.01.038

Clarridge, J.E. (2004). Impact of 16S rRNA gene sequence analysis for identification of bacteria on clinical microbiology and infectious diseases. Clinical microbiology reviews, 17,840-862. https://doi.org/10.1128/cmr.17.4.840-862.2004

Altschulz, S.F., Gish, W., Miller, W., Myers, E.W., Lipman, D.J. (1990). Basic local alignment search tool. Journal of Molecular Biology., 215,403410. https://doi.org/10.1016/s0022-2836(05)80360-2

OECD/OCDE 425 Adopted: 17th December 2001 1/26 OECD Guideline for testing of chemicals Acute Oral Toxicity - Up-and-Down Procedure Test No. 425: Acute Oral Toxicity: Up-and-Down Procedure

https://ntp.niehs.nih.gov/iccvam/suppdocs/feddocs/oecd/oecdtg425.pdf. https://d oi.org/10.1787/9789264071049-en

Parasuraman, S., Raveendran, R., Kesavan, R. (2010). Blood sample collection in small laboratory animals. Journal of Pharmacology and Pharmacotherapetics, 1, 87-93. https://doi.org/10.4103/0976-500x.72350

Bhosale, U.,Yegnanarayan, R., Prachi, P., Zambare,M., Somani, R.S. (2011) Study of CNS depressant and behavioral activity of an ethanol extract ofAchyranthes Aspera (Chirchita) in mouse model. Annals of Neuroscience, 18 , 44-47.

https://doi.org/10.5214/ans.0972.7531.1118204
Yamaguchi, T., Kawahara, R., Katsukawa, C., Kanki, M., Harada, T., Yonogi, S., Iwasaki, S., Uehara, H., Okajima, S., Nishimura, H., Motomura, K., Miyazono, M., Kumeda, Y., Kawatsu, K. (2018). Food-Borne Outbreak of Group G Streptococcal Pharyngitis in a School Dormitory in Osaka, Japan. Journal of Clinical Microbiology, 56, 1-17. https://doi.org/10.1128/jcm.0188417

Mahendran, G., Thamotharan, G., Sengottuvelu, S., Bai, V.N. (2014). Evaluation of Anticonvulsant, Sedative, Anxiolytic, and Phytochemical Profile of the Methanol Extract from the Aerial Parts of Swertia corymbosa (Griseb.) Wight ex C.B. Clarke. Biomed Research International, 2014, 1 9. https://doi.org/10.1155/2014/542385

Carpenter, R.E., Watt, M.J., Forster, G.L., Overli, O., Bockholt, C., Renner, K.J., et al. (2007). Corticotropin releasing factor induces anxiogenic locomotion in trout and alters serotonergic and dopaminergic activity. Hormones and Behavior, $52,600-611$.

https://doi.org/10.1016/j.yhbeh.2007.07.012

Asinof, S.K., Paine, T.A. (2013). Inhibition of GABA synthesis in the prefrontal cortex increases locomotor activity but does not affect attention in the 5-choice serial reaction time task. Neuropharmacology, 65, 3947. https://doi.org/10.1016/j.neuropharm.2012.09.009

Pum, M.E., Huston, J.P., Müller, C.P. (2009). The role of cortical serotonin in anxiety and locomotor activity in Wistar rats. Behavioral Neuroscience, 123, 449-454. https://doi.org/10.1037/a0014478

Takakusaki, K., Chiba, R., Nozu, T., Okumura, T. (2016). Brainstem control of muscle tone with special reference to the role of the mesopontin tegmentum and medullary reticulospinal systems. Journal of Neural Transmission, 123, 695-729.

https://doi.org/10.1007/s00702-015-1475-4

Johnson-Wimbley, T.D., \& Graham, D.Y. (2011). Diagnosis and management of iron deficiency anemia in the $21^{\text {st }}$ century. Therapetic Advances in Gastroenterology, 4, 177-184. https://doi.org/10.1177/175683x11398736.

Dede, E.B., Igboh, N.M., Ayalogu, O.A. (2002). Chronic toxicity study of the effect of crude petroleum (Bonny light), kerosene and gasoline on rats using hematological parameters. Journal of Applied Science and Environmental Management, 6, 60-63.

https://doi.org/10.4314/jasem.v6i1.17197

Rajamanickam, V., \& Muthuswamy, N. (2008). Effect of heavy metals induced toxicity on metabolic biomarkers in common carp (Cyprinus carpio L.). Maejo Int. J. Sci. Tech., 2, 192-200.

Thapa, B.R.,\& Anuj, W. (2007). Liver Function Tests and their Interpretation. Indian Journal of Pediatr, 74, 663-671.

Giannini, E.G., Testa, R., Savarino, V. (2005). Liver enzyme alteration: a guide for clinicians. CMAJ, 172, 367-379.

https://doi.org/10.1503/cmaj.1040752 